\title{
IMPROVING STUDENTS' METACOGNITIVE AWARENESS THROUGH IMPLEMENTING LEARNING JOURNAL
}

\author{
Ulfa Nurajizah, Sistiana Windyariani*, and Setiono \\ Department of Biology Education, Faculty of Teacher Training and Education, \\ University of Muhammadiyah Sukabumi, West Java, Indonesia \\ *Corresponding e-mail: windyariani@gmail.com
}

\begin{abstract}
The process of learning and understanding of science has relevance to the level of metacognitive awareness. The purpose of this study was to find out whether the use of learning journals have an effect on students' metacognitive awareness. This study was quasi-experimental research with non-equivalent pretest-posttest control group design. The subjects of this study were second semester of VII grade students of State Junior High School 5 of Sukabumi in 2017-2018 academic year. Metacoginitive awareness was measured by using Metacognitive Awareness Inventory (MAI). The data obtained from pretest and posttest were calculated into $N$-gain score. These data were analyzed by using independent $t$ test. The results showed that $N$-gain score for metacognitive awareness in experimental and control class were 0.70 and 0.22 in sequence. Meanwhile, the t-test results indicated that there was a significant difference between learning by using learning journals and without using learning journals in increasing students' metacognitive awareness. It showed that students metacognitive awareness in the experimental class were better than the control class. It can be suggested that implementing learning journals is potential media in improving students' metacognitive awareness.
\end{abstract}

Keywords: Learning journals, metacognitive awareness, science learning

(C) 2018 Department of Biology Education, FTTE, University of Muhammadiyah Malang, Indonesia

\section{INTRODUCTION}

Student activity in building its own knowledge is a priority in science learning. During the learning process, students are expected to be more independent in constructing their knowledge. In the process of constructing such knowledge, students are required to be able to compare the prior knowledge with the new knowledge they have gained. Metacognitive plays an important role in this process (Adhitama, Kusnadi, \& Supriatno, 2014; Ramadani, Fauzi, Sukmawati, \& Corebima, 2015).

Metacognitive is knowledge and beliefs about cognitive processes of a person and his conscious efforts to engage in the process of behaving and thinking (Munir, 2016; Scott, 2015) about thinking itself (Nasution \& Rezeqi, 2015). There are two components of metacognitive: knowledge and regulation. Metacognitive knowledge includes knowledge of one's position as learning and the factors that influence his achievement, knowledge of strategy, and knowledge of what and why to use the strategy. Metacognitive regulation includes the process of monitoring cognition, such as planning activities and evaluating the efficacy of monitoring processes and strategies (Jeronen, Palmberg, \& Tli-Panula, 2016; Panchu, Bahuleyan, Seethalakshmi, \& Thomas, 2016a; Tanner, 2012).

Improving metacognitive awareness is important developmental and educational goals (Ridley, Schultz, Glanz, \& Weinstein, 1992; Sendag \& Odabasi, 2009). Metacognitive has an important role in learning science. The reason, learning science is not just about facts, concepts, or principles but also a learning process for students in everyday life. Thus, in the science learning process, students need to build their own knowledge independently. Based on the several previous study, such as the studies that conducted by Hidayati (2016); Jagals and Walt (2016); Kallio, Virta, and Kallio (2018); Lajeng (2017); Okoza, Aluede, 
and Owens-Sogolo, (2013); and also Tamsyani (2016), a good level of metacognitive awareness is related to the ability of student to better design, monitor, evaluate, and reflect on the learning process consciously. It will help student to become more independent and confident in learning. Therefore, the empowerment of students' metacognitive during learning is an effort that must be done by the teacher or lecturer (Fauzi, 2013; Panchu, Bahuleyan, Seethalakshmi, \& Thomas, 2016b; Ramadani et al., 2015). In this regard, students who have good metacognitive awareness will learn well than who do not have good metacognitive awareness (Pantiwati \& Husamah, 2017). If students already have an interest and passion in learning and participate in understanding the material, as well as can be responsible for their own learning, the students are already aware of their metacognitive (Yulianingtyas, Budiasih, \& Marfuah, 2017).

In fact, based on direct interviews with teachers at the State Junior High School (SJHS) 5 of Sukabumi, it is found that students' metacognitive awareness is still low, and students have different levels of knowledge different levels of learning. Some students are active and know how to learn and are able to use their knowledge, but there are those with an average level of intelligence who are trying hard to find their strengths and weaknesses. Some students are passive without knowing how to understand what is being taught, more than a half of students have difficulties in understanding the subject matter. Accordingly, a learning that can develop students' metacognitive awareness is required to face the problem.

One of the potential solution that can be used to develop students' metacognitive awareness in learning is by writing learning journals. Learning journals is a way for students to collect information for self-analysis and reflection of feelings, personal opinions, and even expectations or fears during learning (Jado, 2015; Wahdah, Jufri, \& Zulkifli, 2016). By writing learning journals, they will be accustomed to control their learning as well as engage themselves with learning reflections, become active and recognize their responsibilities as students in every learning process (Damayanti, 2009; Fitria, Andriani, \& Muslim, 2016; Triana, 2012) .

The use of learning journals in the learning process has been conducted by some researchers, among others, research conducted by Fathonah, Ibnu, and Suharti (2016) showed that preparation of learning journals would help students in planning lessons, monitoring, controlling progress, and evaluating learning outcomes that have been achieved. Meanwhile, according to Windasari, Hasanuddin, and Hasanuddin, (2016), learning journal can be used to help less confident students in expressing the difficulties experienced during the learning process. Thus, teachers or lecturers can take advantage of learning journal as evaluation during learning.

However, studies that examine the implementation of learning journal as a solution for improving students' metacognitive awareness, especially Indonesian JHS students in environmental topics are still hard to find. The studies by Fathonah et al. (2016), Husamah (2015), Jado (2015) and Lukitasari, Susilo, Ibrohim, and Corebima (2014) were conducted in universities, whereas the studies by Fauzi (2013), Heswandi, Muhali, and Raehanah (2018), Jagals and Walt (2016), Lajeng (2017), Ramadani et al. (2015). Windasari et al. (2016) and Yulianingtyas et al. (2017) were conducted in senior high school. Moreover, those studies generally did not examine the effect of learning journal on metacognitive awareness. Noted, only Jado (2015) and Yulianingtyas et al. (2017) studies that examine the effect of learning journals, where, as mentioned earlier, Jado (2015) conducted his study at University, while Yulianingtyas et al. (2017) was in high school.

Interaction between living organism and environment is a subject matter related to the nature of daily life that requires activeness and conscious knowledge building. If students are given learning journals gradually, there is a possibility the students will be aware of their metacognitive. In learning journals there are determinations of what students already know and what they do not know, by using subject matter of interaction between living organisms and their environment, they will be able to see and write down what they know and what they do not know.

\section{METHOD}

This research was quasi-experimental with 'non-equivalent pretest-posttest control group design'. The experimental class used learning journals while the control class did not use the 
learning journals. The populations of this research were students of SJHS 5 of Sukabumi on second semester of 2017-2018. The samples were class of VII-D as experimental class and VII-C as control class. This research used purposive sampling refers to Arikunto (2010).

The instrument in this study was metacognitive awareness instrument, including 8 metacognition awareness indicators, adopted from Metacognitive Awareness Inventory (MAI) developed by Schraw and Dennison (1994) on Likert scale. The metacognitive awareness data was obtained from the test results before and after the treatment. Then, pretest and posttest data were calculated become normalized gain ( $\mathrm{N}$-gain).

Differences in N-gain results of students' metacognitive awareness were tested using independent $\mathrm{t}$-tests. Before performing t-test, the assumption test was conducted. Normality assumption tested by using chi square test while homogeneity assumption using Levene's test.

\section{RESULTS AND DISCUSSION}

The result of students' metacognitive awareness on the experimental class and control class are presented in Table 1. The results show that metacognitive awareness in the experimental and control class has increased. However, the $\mathrm{N}$-gain score in the experimental class $(0.70)$ is higher than the control class (0.22).

Table 1. Average score of metacognitive awareness

\begin{tabular}{lccc}
\hline \multirow{2}{*}{ Class } & \multicolumn{3}{c}{ Average score } \\
\cline { 2 - 4 } & Pretest & Posttest & N-gain \\
\hline Experimental & 66 & 89.82 & 0.70 \\
Control & 66 & 73.71 & 0.22 \\
\hline
\end{tabular}

The results of the pre-requisite test indicate that the $\mathrm{N}$-gain scores in the experimental and control classes have met the assumptions of normality and homogeneity (see Table 2).

Table 2. The result of assumption test

\begin{tabular}{lcc}
\hline \multicolumn{1}{c}{ Assumption } & Value & Critical value \\
\hline $\begin{array}{l}\text { Normality of } \\
\text { experimental class }\end{array}$ & 5.40 & 7.81 \\
$\begin{array}{l}\text { Normality of } \\
\text { control class }\end{array}$ & 3.60 & 7.81 \\
$\begin{array}{l}\text { Homogeneity of the } \\
\text { variant }\end{array}$ & 1.44 & 1.69 \\
\hline
\end{tabular}

The $\chi_{\text {value }}^{2}$ scores on the experimental class and control class are sequentially (5.40) and
(3.60) lower than the $\chi_{\text {critical value }}^{2}(7.81)$ so that the data is normally distributed, while the variance of both data is also homogeneous $\left[F_{\text {value }}(1.44)<F_{\text {critical value }}(1.69)\right]$.

The result of independent $\mathrm{t}$-test shows that $t_{\text {value }}(19.44)$ is higher than $t_{\text {critical value }}(1.99)$ as described in Table 3. Thus, the null hypothesis was rejected. The research hypothesis which states that "there is a difference between the metacognitive awareness between experimental class and control class" was accepted. Therefore, based on Table 1 and Table 3, the results of this study can be interpreted "the implementation of learning journals affect the level of students' metacognitive awareness".

Table 3. The result of independent t-test

\begin{tabular}{cc}
\hline $\mathbf{t}_{\text {value }}$ & $\mathbf{t}_{\text {critical value }}$ \\
\hline 19.44 & 1.99 \\
\hline
\end{tabular}

At the beginning of the learning activities, students are given a metacognitive awareness test (pretest). The test results show that the mean scores of metacognitive awareness in control and experimental class are respectively 65.51 and 65.95. This happens because at the beginning of learning, students have not been given learning by using learning journals. Thus, the scores of both class were equal. The results are in accordance with the research conducted by Heswandi et al. (2018) which shows that students' metacognitive awareness tends to be low or middle level before being given treatment in the learning process.

Learning journals were notes or writings that work for students to reflect their learning process, such as experience during learning, difficulties and solutions to be done, and recalling what they had learned. This was in line with Lukitasari, Susilo, Ibrohim, and Corebima, (2014) who stated that writing learning journals is an activity that can be accustomed to train the thinking process while improving students' understanding of concepts. In a learning process, when students are asked to describe learning experience they have acquired, students will realize and know what they are experiencing and are able to express it in writing; this is an independent learning strategy using learning journals. Yulianingtyas et al. (2017) was argued that writing learning journals will encourage students' metacognitive awareness, within enabling students to consciously know what they have experienced during the learning process. 


\section{$N$-Gain ratio of each metacognitive} awareness indicator

Comparison of N-gain metacognitive awareness indicator between experimental and control class can be seen in the Figure 1. Based on the Figure 1, comparison of each metacognitive awareness indicator showed that there were differences between experimental and control class. Based on the average N-gain results, the students' metacognitive awareness in the experimental class was superior to the control class. In the experimental class, eight indicators studied had an average of 0.70 whereas the control class had an average of 0.22 . That way the experimental class was categorized as medium and the control class was low.

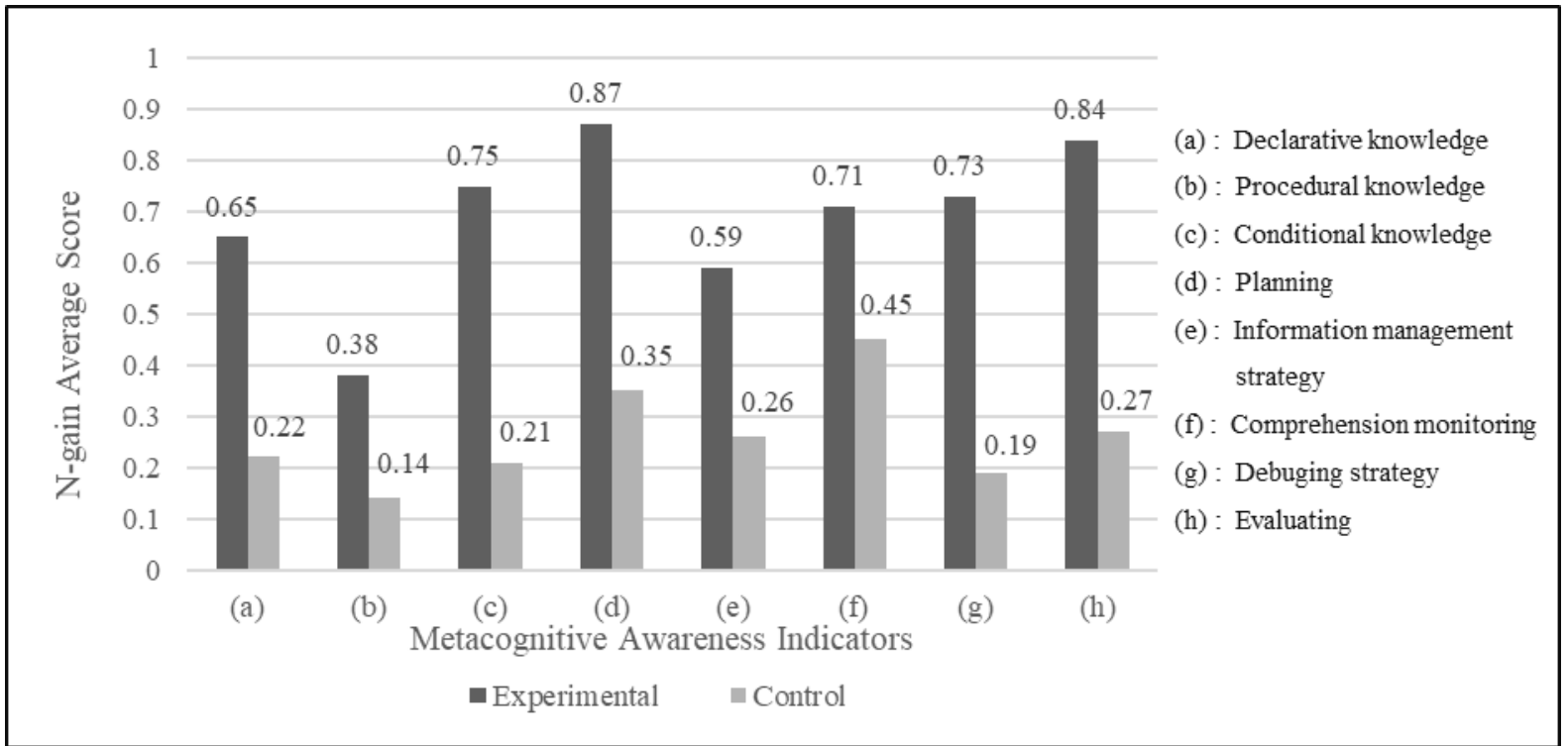

Figure 1. Comparison of metacognitive awareness in experimental and control class

Figure 1 shows in more detail that based on the average of $\mathrm{N}$-gain in the experimental class there are five high metacognitive awareness indicators that are planning (0.87), evaluating (0.84), conditional knowledge (0.75), debugging strategy (0.73), and comprehension monitoring $(0.71)$. Whereas the others indicator classified as medium are declarative knowledge, information management strategy, and also procedural knowledge with the $\mathrm{N}$-gain score in sequence of $0.65,0.59$, and 0.38 . In addition, the tendency of $\mathrm{N}$-gain score in the control class is at low level, only the indicator of comprehension monitoring and planning are classified as medium with a score of 0.45 and 0.35 .

Planning was a metacognitive indicator whose $\mathrm{N}$-gain score highest in the experimental class. This is predictable because the content of learning journals written by the students has relevance to the planning aspect. In learning journals students are accustomed to writing out how their learning plans are like the reference sources to read and the how many times they are need to master a learning objective. Sensitivity to the aspects of planning that grow in the learning process of students at the same time were impacted to the other metacognitive awareness indicators. This can be seen from the high conditional knowledge score, which means the students are able to identify the difficulties they face up during learning process to what kind of learning strategy they can plan to overcome the obstacles. This in line with Adhitama et al., (2014); Jagals and Walt (2016); Munir (2016); Schraw and Graham (1997); and Tzohar-Rozen and Kramarski (2014) which states that metacognitive is the knowledge and beliefs about how to engage in the process of behaving and thinking including their ability to evaluate learning outcomes and developing learning plans that accommodate specific strategies or steps according to the obstacles and challenges they have identified.

Habituated of learning journals in the process of learning in experimental class according to the statement Kallio et al. (2018); Okoza et al. (2013); Raaijmakers et al. (2018); Tzohar-Rozen and Kramarski (2014) are also able to teach and nurture the sensitivity and awareness of students in comprehensively seeing how they learn. This kind of self- 
regulation are important for students in reflecting and monitoring their learning activities. Husamah (2015), Jado (2015), and Nasution and Rezeqi (2015) says that ability will ultimately have an impact on how students will think to reorganize learning processes that include suitable learning strategies to improve their learning achievement.

On the other hand, the control class only indicator of comprehension monitoring and also planning are classified as medium. The others indicator such as declarative knowledge, procedural knowledge, conditional knowledge, information management strategy, debugging strategy and evaluating are low. These situation shows that when compared with the students whom using learning journals, the level of metacognitive sensitivity of students whom do not compose a learning journals is no better.

This happens because in the control class students are not accustomed to writing and identifying how they learn consequently the metacognitive dimension can not effectively develop in the learning process. In fact, to be able to increase metacognitive awareness required a strategic step that develops into good habits (Lajeng, 2017; Lukitasari et al., 2014; Panchu et al., 2016a; Raaijmakers et al., 2018; Schraw \& Graham, 1997; Tanner, 2012).

Habituation of students to write journal should be done periodically and continuously. This is an important step that must be done by the teacher because the metacognitive dimension has relevance to the students character (Goodrich, 1995; Mukhid, 2008). One of them by asking students to write a learning journals at each meeting. Thus, the teachers become easier in assessing and identifying the quality of learning journals as well as enhancing students' metacognitive awareness.

Table 4 shows that most of the students in the experimental class were able to make the learning journals well. This is indicated by the increase in the percentage of the assessment of study journals obtained from each meeting. The $66.9 \%$ gained from the first meeting increased to $90.7 \%$ at the third meeting. Meanwhile, there is an increase of $14.3 \%$ from the assessment at the first meeting until the third meeting.

Table 4. Rubric of learning journals

\begin{tabular}{ccc}
\hline Meeting & Score Average $(\overline{\boldsymbol{x}})$ & Percentage (\%) \\
\hline 1 & 6.0 & 66.9 \\
2 & 6.8 & 76.4 \\
3 & 8.1 & 90.7 \\
\hline
\end{tabular}

Indicators of learning journals that have been organized well can be seen from the existence of student statement that are analysis, reflection, evaluation, and synthesis. Indicators of analysis include statements describing how the learning process they have done, the reflection on the results obtained, the evaluation of strategies and planning better learning strategies based on evaluate they have done. These statements are the foundation upon which an important benchmark is that students' metacognitive awareness has been on the right path for growth (Fitria et al., 2016; Iskandar, 2014).

Increased metacognitive awareness through journal writing in this study can also be explained through stimulus and response approaches (Harrison \& Vallin, 2017; Park, 2003). Journal writing activities that are conditioned within a certain timeframe in the learning process can have an impact on students' metacognitive awareness. During the learning period, students gain a deeper learning experience. Learning is not only about the dimension of knowledge but also on the deeper dimension of thinking and involves all the potential in students to perform better selfregulation (Husamah, 2015; Ridley et al., 1992).

Gradually, students' learning experiences become stronger once they are used to writing analysis of the learning process they are doing, outlining the obstacles and difficulties they encounter during the process, evaluating all the efforts they have made to getting the learning outcomes. The process is continuous so that students are able to think and plan better strategies for subsequent learning (Panchu et al., 2016b; Wahdah et al., 2016). Hidayati (2016) states that writing of learning journals are expected to train students to learn actively in order to find something related to the problems faced. Thus students will be trained to connect problems with their own existing knowledge.

The results of this study reinforce previous research conducted by (Graham, 1994; Jado, 2015; Jagals \& Walt, 2016; Okoza et al., 2013; Yulianingtyas et al., 2017) which states that the learning process combined with learning journals writing is able to optimize students' learning outcomes, especially from the dimensions of metacognitive awareness. Learning journals can also be used as a medium that can help teachers in the effort to identify, 
analyze and develop students' metacognitive awareness.

\section{CONCLUSION}

Implementation of learning journals in the learning process can improve students' metacognitive awareness at a high level in the indicators of planning, conditional knowledge, debugging strategy, and evaluating. In addition, students' ability to write learning journals shows an increase of $14.3 \%$. Thus, the use of learning journals is very potential to be developed in the learning process.

\section{REFERENCES}

Adhitama, R. S., Kusnadi, K., \& Supriatno, B. (2014). Kesadaran metakognitif siswa dalam pembelajaran berbasis proyek pada pokok bahasan pencemaran lingkungan. ASIMILASI, I(1), 2-11.

Arikunto, S. (2010). Research procedure a practical approach. Jakarta: PT Rineka Cipta.

Damayanti, D. P. (2009). Penggunaan jurnal belajar dalam pembelajaran biologi model rancangan alat untuk meningkatkan penguasaan konsep siswa kelas XI IPA SMA Negeri Kebakkramat. Universitas Sebelas Maret Surakarta.

Fathonah, N., Ibnu, S., \& Suharti, S. (2016). Pengaruh pembelajaran berbasis pemecahan masalah berbantuan jurnal belajar terhadap kemampuan metakognitif. $J$. Pijar MIPA, XI(1), 1-6. https://doi.org /10.29303/jpm.v11i1.1

Fauzi, A. (2013). Pengaruh kemampuan akademik terhadap keterampilan metakognitif, hasil belajar biologi, dan retensi siswa SMA Kelas $X$ dengan penerapan strategi pembelajaran Cooperative Script di Malang. Universitas Negeri Malang. https://doi.org/10.13140/ RG.2.2.24659.99363

Fitria, D., Andriani, N., \& Muslim, M. (2016). Efektivitas penerapan learning journal pada pokok bahasan optika geometri siswa kelas X SMA Negeri 1 Indralaya Utara. Jurnal Inovasi Dan Pembelajaran Fisika, $3(1), 1-7$.

Goodrich, H. (1995). Metacognition and character. In The annual meeting of the american educational research association (pp. 1-6). San Fransisco.
Graham, B. (1994). Student journals: A window to metacognitive development. University of Lethbridge.

Harrison, G. M., \& Vallin, L. M. (2017). Evaluating the metacognitive awareness inventory using empirical factor-structure evidence. Metacognition and Learning, 125. https://doi.org/10.1007/s11409-0179176-z

Heswandi, H., Muhali, M., \& Raehanah, R. (2018). Pengaruh model contextual teaching and learning terhadap kesadaran metakognisi dan hasil belajar siswa pada materi larutan penyangga. Jurnal Ilmiah Pendidikan Kimia "Hydrogen," 3(1), 221-227.

Hidayati, N. (2016). Pembelajaran discovery disertai penulisan jurnal belajar untuk meningkatkan kemampuan kerja ilmiah siswa kelas VIII 1 SMP Negeri 1 Probolinggo. Jurnal Penelitian Pendidikan IPA, 1(2), 52-61.

Husamah, H. (2015). Blended project based learning: Metacognitive awareness of biology education new students. Journal of Education and Learning, 9(4), 274281. https://doi.org/10.11591/edulearn.v9. i4. 2121

Iskandar, S. M. (2014). Pendekatan Keterampilan metakognitif dalam pembelajaran sains di kelas. Erudio, 2(2), 13-20.

Jado, S. M. A. (2015). The effect of using learning journals on developing selfregulated learning and reflective thinking among pre-service teachers in Jordan. Journal of Education and Practice, 6(5), 89-103.

Jagals, D., \& Walt, M. Van Der. (2016). Enabling metacognitive skills for mathematics problem solving: A collective case study of metacognitive reflection and awareness. African Journal of Research in Mathematics, Science and Technology Education, 20(2), 154-164. https://doi.org/10.1080/18117295.2016.11 92239

Jeronen, E., Palmberg, I., \& Tli-Panula, E. (2016). Teaching methods in biology education and sustainability education including outdoor education for promoting sustainability-A literature review. Education Sciences, 7(1), 1-19. https:// doi.org/10.3390/educsci7010001

Kallio, H., Virta, K., \& Kallio, M. (2018). Modelling the components of meta- 
cognitive awareness. International Journal of Educational Psychology, 7(2), 94-122. https://doi.org/10.17583/ijep.201 8.2789

Lajeng, U. K. A. (2017). Pengaruh model Problem-Based Learning (PBL) terhadap kesadaran metakognitif siswa pada materi laju reaksi. Universitas Islam Negeri Syarif Hidayatullah.

Lukitasari, M., Susilo, H., Ibrohim, I., \& Corebima, A. D. (2014). Lesson study in improving the role of e-portfolio on the metacognitive skill and concept comprehension: a study on cell biology subject in IKIP PGRI Madiun, Indonesia. American Journal of Educational Research, 2(10), 919-924. https://doi.org /10.12691/education-2-10-11

Mukhid, A. (2008). Strategi Self-Regulated Learning (Perspektif Teoritik). Tadris, 3(2), 222-239.

Munir, N. P. (2016). Pengaruh kesadaran metakognitif terhadap motivasi belajar dan kaitannya dengan hasil belajar matematika siswa kelas XI SMA Negeri di Kota Pare-Pare. Al-Khwarizmi: Jurnal Pendidikan Matematika dan Ilmu Pengetahuan ALam, 4(2), 117-128.

Nasution, M. Y., \& Rezeqi, S. (2015). Application of contextual learning to improve critical thinking ability of students in biology teaching and learning strategies class. International Journal of Learning, Teaching and Educational Research, 11(3), 109-116.

Okoza, J., Aluede, O., \& Owens-Sogolo, O. (2013). Assessing students' metacognitive awareness of learning strategies among secondary school students in Edo State, Nigeria. Research in Education, (90), 8397. https://doi.org/10.7227/RIE.90.1.6

Panchu, P., Bahuleyan, B., Seethalakshmi, K., \& Thomas, T. (2016a). Metacognitive awareness- evaluation and implications in medical students. International Journal of Research in Medical Sciences, 4(8), 3570 3575.https://doi.org/10.18203/2320-6012. ijrms20162331

Panchu, P., Bahuleyan, B., Seethalakshmi, K., \& Thomas, T. (2016b). Metacognitive knowledge : a tool for academic success. International Journal of Medical Research Professionals, 2(5), 3-6. https:// doi.org/10.21276/ijmrp.2016.2.5.026

Pantiwati, Y., \& Husamah. (2017). Self and peer assessments in active learning model to increase metacognitive awareness and cognitive abilities. International Journal of Instruction, 10(4), 185-202. https://doi. org/10.12973/iji.2017.10411a

Park, C. (2003). Engaging students in the learning process: The learning journal. Journal of Geography in Higher Education, 27(2), 183-199. https://doi.org/ 10.1080/03098260305675

Raaijmakers, S. F., Baars, M., Schaap, L., Paas, F., van Merriënboer, J., \& van Gog, T. (2018). Training self-regulated learning skills with video modeling examples: do task-selection skills transfer? Instructional Science, 46(2), 273-290. https://doi.org /10.1007/s11251-017-9434-0

Ramadani, S. D., Fauzi, A., Sukmawati, I., \& Corebima, A. D. (2015). Perbandingan potensi strategi pembelajaran cooperative script dan reciprocal teaching dalam memberdayakan keterampilan metakognitif, hasil belajar Biologi, dan retensi siswa SMA. In Proceedings of the 2nd Seminar \& Workshop Nasional Biologi, IPA, dan Pembelajarannya FMIPA UM (pp. 655-661). Malang: Biologi FMIPA UM.

Ridley, D. S., Schultz, P. A., Glanz, R. S., \& Weinstein, C. E. (1992). Self-regulated learning: The interactive influence of metacognitive awareness and goal-setting. Journal of Experimental Education, 60(4), 293-306. https://doi.org/10.1080/0022097 3.1992 .9943867

Schraw, G., \& Dennison, R. S. (1994). Assesing Metacognitive Awareness. Contemporary Educational Pschology, 19, 460-475. https://doi.org/10.1006/ceps.1994.1033

Schraw, G., \& Graham, T. (1997). Helping gifted students develop metacognitive awareness. Roeper Review, 20(1), 4-8. https://doi.org/10.1080/027831997095538 42

Scott, C. L. (2015). The futures of learning 3: What kind of pedagogies for the 21st century? Education Research and Foresight. https://doi.org/10.1016/j.pse.20 15.08.005

Sendag, S., \& Odabasi, H. F. (2009). Effects of an online problem based learning course on content knowledge acquisition and critical thinking skills. Computers \& Education, 53, 132-141. https://doi.org /10.1016/j.com pedu.2009.01.008 
Tamsyani, W. (2016). Pengaruh model pembelajaran dan kesadaran metakognitif terhadap hasil belajar peserta didik SMA dalam materi pokok asam basa. Journal of EST, 2(April), 10-25. https://doi.org/10. 26858/est.v2i1.1887

Tanner, K. D. (2012). Promoting student metacognition. CBE Life Sciences Education, 11(2), 113-120. https://doi. org/10.1187/cbe.12-03-0033

Triana, E. (2012). Penerapan jurnal belajar terhadap peningkatan hasil belajar siswa pada konsep pencemaran dan kerusakan lingkungan. IAIN Syekh Nurjati Cirebon.

Tzohar-Rozen, M., \& Kramarski, B. (2014). Metacognition, motivation, and emotions: contribution of self-regulated learning to solving mathematical problems. Global Education Review, 1(4), 76-95.

Wahdah, N. F., Jufri, A. W., \& Zulkifli, L.
(2016). Jurnal belajar sebagai sarana pengembangan kemampuan metakognisi siswa. Jurnal Pijar MIPA, XI(1), 70-74. https://doi.org/10.14800/ics.95

Windasari, C., Hasanuddin, H., \& Hasanuddin, H. (2016). Pengaruh model guided discovery terhadap kesadaran metakognitif dan hasil belajar kognitif peserta didik pada materi sistem reproduksi manusia di MAS Babun Najah Banda Aceh. Jurnal Biotik, 4(1), 66-74.

Yulianingtyas, E., Budiasih, E., \& Marfuah, S. (2017). Pengaruh penggunaan jurnal belajar dalam model pembelajaran learning cycle 6e terhadap kesadaran metakognitif siswa SMAN 8 Malang pada materi redoks. Jurnal Pendidikan: Teori, Penelitian, dan Pengembangan, 2(5), 724-730. 